\title{
Personagens caipiras da cultura popular: entrevista com Oswaldo Elias Xidieh
}

\author{
PAULO DE SALLES OLIVEIRA ${ }^{I}$
}

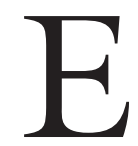

NTREVISTA com o professor Oswaldo Elias Xidieh, realizada na cidade de Marília (SP), no início de 1991, ano em que a Unesp local promoveu um colóquio, "Encontro com Mestre Xidieh", nos dias 2 e 3 de abril, reunindo vários professores e pesquisadores. Na ocasião, além da discussão de sua obra, foi-lhe outorgado o título de professor emérito. Oswaldo Elias Xidieh escreveu vários textos e dois livros: Narrativas pias populares (1967) e Semana santa cabocla (1972), ambos editados pelo Instituto de Estudos Brasileiros da USP. O primeiro mereceu uma segunda edição em 1993 (Ed. Itatiaia/Edusp), mas inexplicavelmente sua distribuição foi precária. Xidieh Faleceu em 2001.

Paulo de Salles Oliveira - Sei que você nasceu em São Paulo, mas sua formação, na infância e na juventude, se deu em várias cidades do interior e contou com a presença de várias personagens do mundo rural. Seria bom se pudéssemos falar aqui sobre cada uma dessas pessoas.

Osvaldo Elias Xidieh - Era uma educação difusa, compreende? Não foi nada intencional. Foi assim, por ser, por si. Não sei bem como explicar isso. Eu mesmo não sabia que estava vivendo certo tipo de cultura; fui saber depois que estudei na Faculdade de Filosofia. Foi quando percebi que aquele mundo (da faculdade) não era o meu, absolutamente. Botei a mão na cabeça e me perguntei "O que é que eu vou fazer aqui?"

PSO - Esse estranhamento se deve muito ao fato de você fazer questão de preservar-se como caipira. Por isso, seria bom conversarmos sobre as pessoas mais marcantes para você. Quais foram essas pessoas que tiveram presença importante em sua infância? Qual magia elas exerceram sobre você?

OEX - Olhe, eu nasci em 1915 e até 1922 estive em Pilar (do Sul). Essa foi uma época crucial, mesmo. Fui viver com caipiras, com caboclos, com meninos descendentes de caipiras, filhos de sitiantes. Pilar era numa vila isolada, sem estrada de ferro, sem comunicação nenhuma com Sorocaba. Era uma vilazinha voltada para si mesma. Então, eu vivi aquilo tudo. Quando criança, eu tinha o ano dividido entre brinquedos e coisas pra fazer. Era o tempo de correr o arco, de fazer papagaio; era tempo de fazer arapuca, era o tempo de pegar tanajura, era o tempo de colher fruta, ingá, tempo de brincar. E era tempo de estar atento 
a tudo aquilo que a gente ouvia, que a gente escutava. Então, eu escutava essas pessoas mais chegadas, adultas, muito amigas, como Mãe Domingas, uma preta, já idosa, mas que não tinha sido escrava, não. Era já alforriada. E também Nhana Carneira, outra preta, mais velha. Com Nhana Carneira aprendemos a fazer fivelinhas para a festa de São Gonçalo, colher bambu para enfeitar a capela, fazer oratoriozinho, arrumar plantas, flores - como palmas - para enfeitar a capelinha de São João. "Capelinha de melão é de São João, é de rosa, é de cravo, é de manjericão", isso, eu ouvi criança.

PSO - E como eram essas pessoas? Fale um pouco mais delas.

OEX - Velhas, analfabetas. Hoje eu sei que eram analfabetas, mas sabiam tanta coisa! Falavam muita coisa em quimbundo. Por exemplo, quando eu estava meio enfezado, eles perguntavam em quimbundo: "por que o menino não faz um cumprimento para mim?”. Sabiam que eu estava de cara feia, não é? Eu não respondia. Eu só entendia, mas não respondia. Sabia que era cara feia.

Muito bem. Essa primeira fase termina em 1922, quando fui para Taquaritinga. Depois, em 1925, voltei e passei mais um ano em Pilar. Nhana Carneira tinha morrido, mas Mãe Domingas estava viva ainda. Então, nessa ocasião, conheci Colodino, uma espécie de peão que morava na invernada de meu tio-avô Miguel Gabriel. Foi com Colodino que aprendi sobre plantas, a evitar certas plantas. A conhecer aquelas que eram boas, como colhê-las, como prepará-las, quais plantas deviam ser usadas, quais partes - a da folha, do galho, da raiz, ou então do sumo. Ou ainda, outras coisas como o vinho do jatobá. Você fura a árvore e o vinho sai. Chamam até de "suco de vinho". É muito forte para combater a fraqueza, bom para anemia. Colodino me ensinou a fazer arapuca, que eu nunca usei porque tinha dó de pegar passarinho. Ele me ensinou também a fazer cova para pegar peixe, a fazer rede, me ensinou muita coisa. Só não conseguiu me ensinar direitinho a andar a cavalo. Porque eu não tinha jeito mesmo para isso! Andava muito feio a cavalo. Com ele aprendi, também, as coisas misteriosas que acontecem: o que é o Boitatá, que anda por aí, o que é uma mula sem cabeça, o que é a porta dos sete leitões, o que é mão-furada, o que é corpo seco.

PSO - Essas histórias chegavam a assustar você?

OEX - Não. De noite, quando eu ouvia o vento assoprar eu pensava: “Tá passando por aí. Mas Boitatá pra lá, eu pra cá. Coisa ruim pra lá e eu pra cá”. E ficava sossegado. É como aquela simpatia de fumacinha prá lá e a Santa pra cá. Ele me ensinava também a me defender. É o abrenuncio, não é? Arrenego, arrenego. Mas tinha medo de outras coisas que ele falava. Havia lá um senhor, que faleceu, e Colodino me dizia: "Você sabe que ele fica sentado aqui na porteira, de noite?". Disso aí eu tinha medo.

PSO - Nunca foi lá para conferir, não é?

OEX - Não! Tinha medo mesmo! Em 1934, voltamos a Pilar. Então foi o grande conhecimento com Felisbino Beurat, de origem francesa, mas caipira, sitiante, tio Bino. Ele tinha sítio perto do ribeirão. Foi com ele que eu aprendi 
que muitas imagens, grandes, de santos da igreja, mesmo da capela dele, eram só cavalete. Eu me espantei quando me falou: "Ué, você não sabia que santo não tem bunda?”. Com tio Bino aprendi leitura de mão, a ver cartas, a fazer adivinhação, a pintar coluna de reza com a chave. Amarrava-se uma chave dentro do livro de oração, e duas pessoas seguravam pelo cabinho da chave, e faziam perguntas. Quanta coisa que eu aprendi. Eu vi tudo isso.

Tio Bino me ensinou curar uma porção de coisas. Por exemplo: simpatia para curar coceira, para curar caxumba, para curar frieira, me ensinou tudo isso. Lembra-se daquela mistura de limão com enxofre para cicatrizar? Eu aprendi com ele; é para curar coceira. Ou então passar cuspe com cinzas, ele me ensinou. Passar alvaiade no pé pra curar frieira. Esfregar limão na cabeça para curar caspa. Em 1934, fui para Itapetininga. Em 1937, voltei para Pilar. Era uma constante, não é? Um sonho, eu adorava aquilo. Em 1937, fui parar na Faculdade de Filosofia. Foi difícil. Eu tinha muita dificuldade de compreender as pessoas, sabe? Porque eu não sabia que coisa estaria atrás daquilo que um colega estava se referindo. Ao passo que quando alguém de Pilar falava, eu tinha todo o mundo en arriére, todas as coisas por detrás daquilo; então, entendia perfeitamente. A mesma coisa ocorreu quando conheci sírios e italianos; foi muito difícil. Houve um tempo, em Taquaritinga, isso foi em 1923, 24 até 34. Terminei o curso primário lá. Foi quando aconteceu a grande surpresa para mim, como caipira: conhecer o italiano e o sírio. Surpresa e um pouco de medo. Surpresa porque Mãe Domingas costumava dizer que tudo quanto era carcamano, tudo quanto era estrangeiro não era só italiano, não, era tudo quanto era estrangeiro - "vinha de um pouco pra lá de arriba da Bahia”. Depois, eu tive um certo medo porque a Gabriela, que também era negra, dizia que "turco só come sernambi (pequeno molusco que vive na costa brasileira, sob a areia) na praia, mas ninguém sabe o que é sernambi”. E justamente meus avós eram sírios. Você imagina o espanto que eu tive com aquelas coisas que eu nunca ouvi falar; aquela coisa que eu não entendia, não é? Mas foi tudo muito agradável porque eles tinham festas, tinham danças, tinham reuniões. Era uma porção de tios, imagine que minha mãe teve onze irmãos e irmãs, aquele mundo de gente, de tudo quanto é idade. Meu tio Sebastião era mais novo do que eu! Coisa, assim, espantosa, não é? Tudo diferente.

PSO - Você nunca conbeceu sernambi?

OEX - Não, ninguém sabe o que é sernambi. Nunca vi o que é sernambi. Às vezes, eu tenho uma imagem na cabeça de que é um pedaço de gente bem cozida assim, não sei bem o que é (fala brincando e dando risada). Então me acomodei com isso tudo porque vivia na casa deles. Mas como eu não pude me matricular no grupo escolar - sou alfabetizado desde os cinco anos de idade me puseram no Dante Alighieri. Era um casarão achatado, imenso, uma grande porta, janelas; era só um salão, com uma edícula, um banheiro e a cozinha, onde eles davam leite e lanche para as crianças. Mas lá havia um salão só; não era dividido por classe, mas dividido por livro. Cada fileira lia um livro, de acordo com 
o progresso. Eu caí na fileira do livro “Cuore”, de De Amicis. Fiquei ali pouco tempo. Porque isso era mês de setembro. Logo passou outubro e,quando foi o ano seguinte, me puseram no grupo escolar. Mas, eu aprendi coisas fabulosas. Toda uma linguagem diferente, que não era aquela do caipira.

O que mais me impressionava era o costume de certas casas italianas. Até hoje eu não me esqueço da senhora Maria Curti cortando pão. Ela pegava aquela broa enorme, receita italiana, colocava contra o peito com a mão esquerda e com a direita cortava as fatias. Era uma coisa ritual, meio religiosa, nunca me esqueci disso, nunca me esqueci. Era uma coisa linda pra mim, sabe?

PSO - E era um gesto demorado...

OEX - Demorado. Era quase um ritual. Fatia para um, para outro, para todo mundo... Nada sobrava, mas era suficiente para alimentar; não havia repetição das coisas. Mas tive um susto um dia, num sítio em Jurema, perto de Taquaritinga. Quando serviam a refeição, vinha a salada no fim. Eles comem a salada depois da refeição, sabia disso? Italianos comem a salada depois. Foi quando o dono da casa perguntou: "Con sbruffo o senza sbruffo?". Eu fiquei assim, sem saber. Outro lá falou: "Voglio sbruffo!". E ele tomou um gole de tempero na boca, misturou como num bochecho, e soltou no meio do prato de salada. (Risos)

Aprendi mais coisa convivendo com os italianos. Não é parecido com o folclore brasileiro. Aprendi a existência de fadas, a Fata Befana, uma fada que traz benefício, ajuda. Também muitos ditados, piano piano si va lontano e mais coisas.

Em Taquaritinga, conheci Hilário dos Santos, um preto velho. Foi a única vez que eu vi um Boi-Bumbá na minha vida. Ocorreu em 1923 e nunca mais eu vi uma coisa dessas. Ele tinha sido escravo, estava velhinho, e me ensinou rezas. Muita reza e muita reza brava: a de Santa Catarina, para fechar corpo, a de São Jorge e histórias, muitas histórias. Ele me contava como tinha sido proclamada a monarquia em Taquaritinga, no fim do século (XIX), mas durou só um dia porque outras cidades não acompanharam o movimento que tinha sido combinado: São Carlos, Campinas... mas só Taquaritinga (o realizou). No entanto, as lembranças da monarquia ficaram no brasão da cidade ou na coroa imperial. E o clube principal da cidade é o Clube Imperial. Essa coisa ninguém tirou, ninguém tirou. E o interessante é que quem promove de fato essa revolução, não são só brasileiros: são italianos. Havia duas alas de Italianos... uma era ligada à religião, ao catolicismo, à monarquia. E outra ala era, como é que se diz?

PSO - Anarquista.

OEX - Anarquista. Com essa ala anarquista, eu aprendi muita coisa, não é? A xingar. Antes, não xingava. E também foi a primeira vez que eu ouvi o hino da Internacional. Foi em 1923, ao amanhecer, no dia do trabalho. Mas foi só sair que logo acabou; logo veio o fascismo. Um belo dia, vieram uns senhores de camisa preta, de calça, não sei o quê, com bandeira, com boné, não era bem um boné, chamavam bibi, com chicotes. Eram fascistas. 
Eu estava falando do Hilário e havia também Nhá Veva. Tinha um pequeno sítio; era uma preta. Mas ela não foi escrava, não. Ela era benzedeira, parteira, ajudava quem quisesse e tivesse necessidade de alguma coisa. Era curandeira e quituteira. Se alguma família precisasse, ela ia ajudar a tomar conta (das crianças), a fazer comida. Era pau para toda obra, muito querida, muito amável, uma grande mulher.

Mais tarde, em Uraraí, voltei a ter contato com benzedeiras. Isso foi em 1931, 1932, um pouquinho de 1933. Havia italianos, mas todos caboclos. Havia sírios, muçulmanos, mas caboclos! Todos caboclos, todos caboclos, mesmo! Foi lá que, através deles, dos remanescentes de caboclos brasileiros, eu aprendi o que era corpo seco, aprendi o que era mãe do ouro, aprendi coisas incríveis, não é?

A mãe do ouro é quando, à noite, você vê um clarão no céu, e depois um estalo - muito feio como um trovão - é porque a mãe de ouro caiu em algum lugar. E quem encontrar aquilo vai encontrar muita fortuna, muita riqueza.

Se você estiver passando pelo Córrego do Macaco, no caminho para Santa Adélia, e ouvir um barulho no mato, não pare! Você vai rezando e vai andando, não pare! Porque o corpo seco vai querer atacar você; você não pare e não acontece nada. Vai em frente e rezando. O que é o corpo seco? Gente que só fez o mal. Há uma quadrinha assim, que lembra isso: "tanto mentiu, tanto roubou..."

"Juntou tanta coisa, tanto dinheiro,

Tanto roubou, tanto mentiu, tanta loucura.

Hoje o que ele tem de seu inteiro

São sete palmos de fundura."

(Seu Selma, Poá)

Gente que só fez maldade, quando morreu, virou o corpo seco. Não tem descanso; fica pra sempre atentando os outros.

PSO - Uma curiosidade acerca dessas pessoas é que são pessoas negras e que sofrem ou podem sofrer, de alguma forma, preconceito. E todas analfabetas. No entanto, são pessoas que tem muita fé, que trazem um ensinamento diverso. Você chegou a intuir que nas práticas e pensamentos dessas pessoas estaria ai uma fonte de saber?

OEX - Não sei. Nunca pensei nisso, nunca. Porque quem está dentro não pensa. Eu não sabia que estava inserido neste tipo de educação difusa, eu não sabia que eu estava sendo diferente, que estava voltado para uma coisa paralela. Agora, em relação ao comportamento perante os negros, este é um traço que vinha desde o tempo do Império. Às pretas velhas, respeito! Elas se transformaram, de certa maneira, em mães de famílias brancas, criaram a gente! Mãe Domingas me criou, e havia já ajudado a criar meu pai, meu tio José. Em outras casas era assim também. Por exemplo, na casa da máquina, havia uma família de pessoas negras que permaneceu lá, como dona da máquina, quando toda família (proprietária) morreu. Ninguém tirou deles, não! 
PSO - Quanto à Mãe Domingas, segundo você mesmo conta, ficou com terras que ficaram sem dono?

OEX - Ah, sim, as chamadas "Terra dos Pretos". Eu perguntava muito. Ela me ensinou a cantar aquela cantiga de quando proclamaram a liberdade dos escravos: "Agora vamos dançar, agora vamos cantar. Que o sol da liberdade da princesa já raiou. E o cativeiro acabou". Ela que me contou isso. Naquela ocasião, em Pilar, havia poucos negros. Eram: ela, a Hélia, a Silvéria, a Paulina e mais essa família da máquina. Foram embora, mas essa gente não era mais escravo porque a família Almeida havia doado uma terra em Saracuí. E, de fato, eu ouvi dizer bem mais tarde, que havia um grupo de negros dessa região, falando em quimbundo, com os costumes antigos. Isso, não fui lá ver.

Bem, eu estava falando de Uraraí. Pois o respeito vem disso - de uma dependência que o branco teve um dia do negro, que foi escravo, depois foi liberto, foi empregado, foi servo para outras coisas. Mãe Domingas dava ordens; até para minha mãe ela dava ordens:

“- Hoje ninguém vai comer carne. Hoje é dia santo de guarda. Hoje vou fazer uma verdura, um caruru, uma couve, vocês vão comer caldo de feijão, caldo de feijão com arroz, só isso. Ninguém vai comer carne."

"- Hoje é véspera de Finados, ninguém sai. Hoje é noite de todos os santos. Não se sai porque é perigoso." Ou então, ela dizia:

“- Agora é Quinta-Feira Santa. Essa noite, véspera da Sexta-Feira Santa, é uma noite aberta. Porque tudo quanto tem de ruim sai por aí. Desde bandido, ladrão, coisa ruim, corpo seco, alma penada, sai tudo por aí pra atentar os outros. Vai até a hora que amanhecer e o galo cantar. Então, você não vai sair na véspera de Sexta-Feira maior, não. Não pode sair."

Toda hora eu volto a Mãe Domingas, não é? E o culpado é você.

Estávamos em Uraraí, uma terra que não era simplesmente lugar de brasileiro, mas de brasileiro de origem italiana, ou mesmo muçulmana, alguns espanhóis, mas todos caboclos, todos caboclos! Todas essas pessoas estrangeiras que se viam no interior, nessa área, assim, isolada - sem meio de transporte, sem comunicação, sem nada - se transformaram em brasileiros. Todo mundo é brasileiro. Mas o caminho importante foi, lá em Uraraí, ouvir as incelências, isto é, os cantos nos velórios, o guardamento, ou então a sentinela, como chamam.

$\mathrm{PSO}-\mathrm{E}$ você chegava a ir a velórios?

OEX - Chegava. Que eu já era grandão, já era moço de ginásio. Então, por exemplo, a cada parte, cada mistério do terço rezado, interrompia-se a reza, e falavam: "Em nome do Pai, do Filho e do Espírito Santo". Também cantavam "Amado Jesus, José, Maria, sejam nossa salvação. Lá na última agonia, dai-nos a Vossa proteção". E voltavam a rezar os Pais-nossos, começavam tudo de novo. Ou então:

"Estrela Dalva abençoada, abençoai esta sessão, acompanhai este pobre corpo para o céu e a salvação, ó Estrela Dalva!" 
Havia muita incelência, me esqueci. Havia uma incelência que falava das três lavadeiras, nunca consegui me recordar daquilo. Eram três lavadeiras tratando da alma do defunto, uma lavava... me esqueci, era muito bonito! Era bonito.

Afora isso, me levaram a ver castrar animais. Eu sei como faz, mas não faço. E também a fazer enxertos. Aí, fui de volta para Taquaritinga e aprendi coisas muito importantes. Coisas que hoje me fazem pensar mal de toda e qualquer teoria, que era aquilo que eu não sabia. Eu aprendi coisas que parecem loucura... me chamavam de louco, não é?

PSO - Explique isso melhor, por favor...

OEX - Isso é a minha velha atitude. No fim de 1933, aprendi uma coisa. Um dia nós fomos a uma benzedeira e ela pediu roupa para determinar que doença a pessoa tinha. E ela acertou! Depois disse para mim: assim como se pode fazer benefícios com a roupa, pode-se fazer malefício também. Tome cuidado! Quando derem sua roupa pra alguém, lave e faça a pessoa experimentar na sua frente, para não passar nada ao dono da roupa. E não prejudicar nem sua a saúde ou sua força ou seu espírito.

E fotografia, não dê pra ninguém! Porque a fotografia, enquanto você estiver vivo, ela é viva também. Essa macumbeira tinha o nome de dona Hermínia. Muito bem. Então fizemos esta experiência: pegamos fotografia de gente viva e de gente morta e fomos ver. Pela radioestesia, se descobre se existe água, se é boa, se é ruim. Assim também é com um pêndulo; o metal determina o que está vivo e o que não está. Fomos tentar fazer isso com fotografias de quem a gente não conhecia. Foi tudo emborcado, tudo misturado, tudo! Depois, com o pêndulo, víamos se ele, colocado sobre a fotografia, girava no sentido do relógio ou não: se sim, está vivo... E para as outras (pessoas), no outro sentido: está morto. Fomos conferir com quem conhecia aquelas pessoas e deu certo! Era a mesma coisa com roupa, não é? Daí por diante, eu sei que isso era uma coisa tida como idiotice, imaginação, ilusão das pessoas, mas é algo que aí está. São teorias antigas, mais ligadas à religião, à magia. Um grande iniciado, talvez, um ilustre cientista, sabe que isso é possível. Mas, para os atuais, não. A teoria é completa? Será que ela atinge tudo? Mas se a teoria é mentirosa, é uma mentira completa? Como se pode atestar? Graças a Deus já passei por tudo, não tenho mais nada para ser, não devo preocupar mais a ninguém, nem ensinar coisa errada a ninguém. Acompanhe quem quiser. Na faculdade, eu não era o caipira? Mas seria muito interessante que eu continuasse a ser o caipira, e eu...

PSO - É interessante a maneira como você resolve isso, o momento em que você se descobre caipira.

OEX - Eu fiquei doente, eu fiquei doente! O que eu sou, então? Um caipira. Como um caipira, eu não pertenço à faculdade, não pertenço a esse mundo intelectual. Estava desconfiado de mim mesmo, sabe? Por que eu não posso ser um bom aluno, um professor modelo, um grande professor de filosofia. Falo um francês tão bonito, bem, entendo, graças a Deus, mas não quero ser outra coisa 
senão um caipira. Por que não quero? Não gosto dessa dicotomia religiosa. Eu sou caboclo. E um caboclo respeita tudo.

PSO - Houve pessoas que te ajudaram nessa reafirmação do caipirismo na Faculdade de Filosofia (da USP)?

OEX - Não, não.

PSO - Ninguém o ajudou?

OEX - Não. Chamavam a mim de caboclo. Eu tinha um português meio esquisito, com o "erre" acentuado. Até na faculdade ainda falava com esse longo "erre", não é? Eu falava: "Tirante o calor que fez hoje, estava muito bom o dia" Veja só: "tirante"! "Eu conheço aí de sobejo." Riam de mim. "Eu estou assistindo em Mogi das Cruzes”. Queria dizer que estava hospedado em Mogi das Cruzes. Riam de mim! "Eu pessui um livro" - eu comprei um livro. Porque lá era terra caipira, não é?

É. Quando fui para Itapetininga, antes da faculdade, em 1935, 1936, descobri um monte de quadrinhas interessantes. Inclusive aquela "A santa vai num barquinho":

"A Virgem vai num barquinho,

Lavrado de paina e seda.

O vento le ajeita o caminho,

um anjo le alumia a vereda"

(cantador na Igreja de Nossa Senhora das Estrelas)

Foi lá que eu conheci, numa festa, junto à Igreja Nossa Senhora das Estrelas. Era tudo muito bonito, mas eu não fazia pesquisa ainda. Quando fui fazer uma pesquisa, o que é que aconteceu? Então conheci um povo, posso dizer, mais rico de informações. Gente rezadora, curandeiros, orientadores, gente de catolicismo de folck, uma beleza, não é? Uma coisa linda, linda, linda! Macumbeiros, quando não tinha Umbanda, mas já existia macumba paulista. Feita por macumbeiros, antigos escravos, como um que tinha sido um escravo de um grande médico de Mogi das Cruzes. Ele ensinava as coisas pra gente, remédios, simpatias, adivinhas. Eu ia fazer pesquisa sobre magia de religião. Foi assim que eu conheci Zé Honorato, dono de sítio lá na montanha. Rezador, tinha oratório, benzia, defumava couro cabeludo. Teve uma vez que eu fiquei meio ruim, e ele veio defumar minha cabeça.

Conheci gente importante, como Alice Tolosa, abençoada. Era parteira, rezadora, benzedeira, conselheira, era tudo! Conhecia ervas, conhecia remédio, conhecia tudo! Eu guardava essas coisas na memória, não dava tempo de escrever. Dona Alice do Socorro, outra grande mulher! Conhecia remédios de vegetais.

PSO - Como você conbeceu estas pessoas da roça?

OEX - Tinham pequenas chácaras. Dona Alice não trabalhava mais porque o marido dela tinha morrido. Era ligada à família muito importante da maçona- 
ria de São Paulo e recebia uma ajuda. Alice Tolosa morava na Vila Ceci, Mogi das Cruzes. Alice do Socorro morava no Bairro do Socorro, em Mogi das Cruzes. Marieta, uma preta macumbeira, morava na Vila Natal. Agora, outras pessoas que me ajudaram bastante e me levaram a conhecer gente para eu pegar as informações. Não que tivessem me informado, mas me levaram para pegar informações, compreende? A Iracema Nunes da Siqueira: Zizica Nunes da Siqueira.

Aprendi muita coisa, muita simpatia, muito ditado, muita narrativa. E ia acontecendo o que eu não esperava acontecer, como aquele pessoal de Moçambique, de congadas, que ainda existia em 1978, em Mogi das Cruzes, antes do padre proibir esse tipo de manifestação, chamada de profana nas festas religiosas, com a reforma na Igreja Católica. Acabou o Moçambique, acabou a Congada, acabou a festa do Divino Espírito Santo. Acabou tudo aquilo da velha tradição. Seu Benedito Assis, da Congada, já velhinho, morreu logo depois. Imagine quem me ajudou, o seu Jorge, de origem alemã, mas acablocado, seu Emílio Duarte, pai de Paulo Duarte. Eles tinham um sítio em Taiaçupeba. Lá ouvi coisas maravilhosas. Um dia fomos dormir e, lá pelas tantas, vimos que o seu Emílio acordou. Depois perguntou:

- "Vocês viram alguma coisa?"

- "Não!"

- "Então vamos lá fora comer laranja." A laranjeira era um tipo de pirâmide, linda mesmo. Eu quis pegar uma vara para pegar laranja. Ele disse:

- "Não bata na laranja! Eu subo na laranjeira." E subiu! Velhinho, ele subiu na laranjeira.

Depois falou:

- "Está sentindo alguma coisa?” Falei:

- "Eu estou sentindo cheiro de incenso. Alguém está queimando alguma madeira por aí."

- "Não é madeira, é incenso mesmo." "Os frades estão rezando a matina, aí."

- "Mas, aqui não tem convento!"

- "Não tem agora, mas teve antes. E tem ainda!"

PSO - A esta época, o que você pesquisava? Que tema, ou temas, estava trabalbando?

OEX - Comecei a fazer um trabalho de Sociologia. Tentei alguma coisa como: "Flutuação de mão de obra e religiosidade numa área suburbana". Era a transformação de um tipo de vida do município de Mogi das Cruzes, que já estava seccionado em muitos municípios como: Poá, Itaquaquecetuba, Ferraz de Vasconcelos. Foi fragmentado e mudado em muita coisa. Também vieram para lá pessoas diferentes, gente de tudo quanto é parte do Brasil, de tudo quanto é parte do estado de São Paulo. A área começou a deixar de ser agrícola ou horticultora, de pequena propriedade, de chácara, para ser industrializada, e 
começar a loteação. Logo depois veio a guerra e, com a guerra, mais problemas ainda. O catolicismo de folck foi-se embora, acabou. Veio a umbanda para substituir. Diante de um tipo de preocupação antiga, da vida tranquila, calma, do homem perante Deus e a natureza, que procurava se resolver através de práticas religiosas antigas, vieram inquietações: por falta de habitação, comida rarefeita, tratamento de saúde quase impossível, educação nenhuma. Então veio a umbanda. Umbanda, que é coisa de cidade mesmo, começou a invadir toda Mogi das Cruzes, vinda do Rio de Janeiro. E muita inquietação também adveio porque a mão de obra que começava a chegar era não qualificada. Um excesso de gente que muitas vezes é levada a fazer coisas desnecessárias, perigosas até. Foi quando tentei acompanhar aquele movimento. Eu vi a mudança daquilo. Não foi só a mudança de catolicismo de folck, não. Foi todo um quadro, de modo de ser, de viver, de existir, de permanecer livre, num grupo social que estava acontecendo. A umbanda era um recurso naquele tempo, naquela década de 40: 1945, 1946, 1947 até 1948, mas deixou de ser quando vieram outros problemas. Quando toda a agricultura, de todo estado de São Paulo foi modificada pela aparição das companhias; o patrão não é mais o patrão, mas alguém que tem uma porção de funcionários para tomar conta daquilo. As fazendas se despovoaram e o tipo de tratamento entre o patrão e o empregado desapareceu, não existe mais. É dá lá, toma cá. É frio, é seco o negócio! E há uma população desalojada das fazendas que vem para a cidade. Manifesta-se aí uma problemática diferente, que nem a umbanda mais resolve. Vai ser o quê, agora? As seitas reformadas de importação. Isso tudo eu passei, vi claramente.

Mas, em Marília logo que fui lecionar, não pude mais pesquisar em campo. Diziam: "Pode pesquisar, mas durante as férias; pode pesquisar, mas sábado e domingo". Mas eu não podia acomodar os cursos para ficar um mês, dois meses em seguida, juntando com férias, e pesquisando em áreas distantes dali. Hoje é diferente.

$\mathrm{Na}$ época, eu não tive nem verba para comprar lanches aos estudantes quando quis leva-los à Colônia Varpa, de menonitas, (na cidade de Tupã)... Consegui ônibus, combustível e chofer, cedidos pelo Brambilla, um empresário da cidade, mas não o dinheiro para o lanche. Ali havia um grupo de imigração letã, cristão e autossuficiente.

\section{PSO - Você conseguia se relacionar bem com eles?}

OEX - Conseguia, como não? Por ser caipira, caboclo e uma pessoa muito simples não tenho barreiras, a não ser que a pessoa me recuse.

A tal pesquisa que deveria ter sido feita está fragmentada nos artigos sobre catolicismo de folk, sobre magia, sobre religião popular. Depois seria um capítulo sobre a Igreja protestante, formada em Poá. Outros seriam sobre os conflitos entre o distrito e o município, entre o consuetudinário e o formalismo, que começava a aparecer. Ninguém mais podia dizer, por exemplo, que iria "quebrar a cara” do prefeito. Não se faz mais isso; se faz agora um requerimento. 
Mas era um tempo em que eu tinha de dar muitas aulas, com disciplinas em áreas diferentes: História, Pedagogia e Ciências Sociais, dezoito aulas por semana!

Todavia, em Marília, coisas boas também aconteceram para mim, no campo da cultura popular. Primeira coisa: foi conhecer seu Batista ferroviário. Seu Batista me levava para um mundo de sonhos, coisas oníricas, além daquelas que aprendi em Taquaritinga, como, por exemplo, os relatos sobre o povo da água. Ele falava daquelas regiões oníricas, de imaginação, de magia. Contava, que às vezes, quando tinha que sair de Marília, há alguns anos atrás, uns trinta anos atrás, ele saía a cavalo para fazer visitas a sítios da região e voltava ao anoitecer. E, para matar a sede, havia uma fonte onde parava. Mas ele notava, também, que na fonte ainda existia uma gente miudinha fazendo alguma atividade. Tudo tão pequenininho, tão bonitinho. Eles diziam: "Espere um pouco antes de por a caneca, que estamos trabalhando!". Depois falavam: "Agora pode por”.

Isso era um sonho. Se eu fosse escritor, só escreveria essas coisas maravilhosas.

PSO - Além deste universo sonhador, você não se deparou com significados inusitados que o povo algumas vezes atribui a determinadas entidades ou fenômenos?

OEX - Quando eu estava resignado a fazer só pesquisas sobre temas populares em Sociologia, me deparei com um problema que era a mudança de certos símbolos. Como se transformam? Como são erodidos por outros fatores sociais, por novas crenças, por novos pensamentos, por nova moda, por novo tipo de comunicação. De que maneira foram sendo corroídos como se fossem um rochedo, uma rocha, que o vento vai devastando ou a chuva. Um destes elementos era a figura do demônio.

Numa sequência de histórias, que estão em Narrativas pias populares, percebi que a imagem do diabo tinha se transformado lentamente. De pessoa de maldade repetitiva, de coisa feia, mesmo, inveterada, mas que, curiosamente, era vencida sempre por criança. Além disso, acabava inevitavelmente perdendo porque a invenção dele redundava invariavelmente num benefício para alguém. $\mathrm{Vi}$ isso. Mas acabei sabendo por seu Antonio, guarda noturno, de um ponto que eu esperava, mas não tinha conseguido encontrar, que foi o de maior humanização do demônio - o demônio amoroso, no "Ponteio do rio abaixo". Mostra um demônio que se levantou contente, fez um barco e foi descendo o rio. Tinha uma viola; e ele então começou a tocar e a cantar. Estava lindo o dia! Sentou-se no barco e ficou muito emocionado, porque, tocando, descobriu um acorde novo. Era um ponteio, o ponteio do rio abaixo. Numa das curvas do rio, ele viu uma lavadeira. Chegou mais perto e era uma moça linda! Ele imediatamente se apaixonou por ela. Então se declarou:

- "Ah, moça! Eu quero você. Eu quero me casar com você. Eu caso com você de qualquer jeito! A gente vai debaixo do pé de aroeira e já casa que o mundo vai ser nosso!" Quando ele falou isso, a moça desconfiou, e lhe disse: 
- "Olhe, eu caso com você. Mas só se você me der um sinal de amor."

- "Que sinal é esse?" - disse ele. A moça fez o sinal da cruz em quatro longos gestos. O demônio então estourou, a viola ficou no chão, bem perto da moça e ele sumiu, se escafedeu. Ela então pegou a viola e foi para casa. Quando escureceu, pensou: "Vou guardar essa viola em cima da mesa. Pode ter alguma prestação, servir para alguma coisa". Foi dormir e, já de noite, ouviu uma música enchendo a casa toda. Era o "Ponteio do rio abaixo". Ela imaginou: "Será que esse um veio só para infernizar a minha vida?”. Levantou-se, pegou o candeeiro, puxou o crucifixo, e foi até a sala de janta. Em cima da mesa estava a viola, tocando sozinha. Neste instante, ela entendeu tudo, tudo, tudo, tudo!

Não é linda a história? Se eu fosse escritor, que coisa linda, não é? Esse um é o modo de o povo se referir a alguma coisa, indiretamente. Sem invocar a coisa má, ruim, doente. Por exemplo: "Ele estava com uma doença ruim, aqui (apontando o local), lá nele". Esse um - não se diz o nome - que é para não invocar, não chamar a presença da pessoa; e lá nele é o ritual de afastamento.

PSO - Caso a pessoa pronunciasse o nome da doença, por ser tão grave, ela poderia contrair...

OEX - Para eles, a doença vem; ela é de fora. É outra coisa antiga, de primitivos, de índios, de caboclos. A doença anda por aí. A gente faz defumação para espantar a doença. A gente faz barulho para que ela não venha. A gente põe uma garrafinha com água benta na porteira de um chiqueiro para batedeira (febre com tremores) não apanhar o porco. Porque a batedeira vem de fora.

Para a doença de cachorro, a gente põe um colar de sabugo no pescoço do cachorro. A doença não pega porque a doença é de fora; nunca é de dentro. O povo se resigna em dizer que ficou doente; a pessoa diz que foi doente; deu a doença nela, veio nela a doença. Hoje talvez seja diferente, a comunicação mudou muito. Mas antes era isso. Expressões como esse um, aquele um são modos de ritual de afastamento, como os instrumentos que certos índios da Austrália tocavam pra afastar os espíritos do mal. O índio, quando abandonava a taba porque morria alguém, fazia uma fogueira antes de ir embora para a doença não acompanhar. Outro costume indígena é dançar uma dança cheia de voltas, de circunvoluções, cheia de vai e vem, de modo a que a doença se perca e não encontre mais a pessoa.

PSO - Estes rituais não estão presentes hoje quando, por exemplo, se vai num cemitério para que as energias negativas ali permaneçam e não sigam com a pessoa?

OEX - Entra-se com o pé direito; na saída, bate-se o pé para deixar a areia. PSO - Você já me contou de pessoas, além destas de que citou, que também o ajudaram nas pesquisas: às vezes eram intermediários; outras, traziam relatos de interesse. Poderia falar delas também?

OEX - Eu não quero me esquecer de uma porção de pessoas, que me ajudaram muito. Tanto diretamente, como informantes, como indicando pessoas, 
situações ou, então, casos. Ou então outras pessoas que me contaram coisas. Por exemplo, além do José Honorato, em Itapeti, em Santo Ângelo havia o José Zarreli, que fabricava bonecos de madeira, que eram usados na macumba. Em Poá, havia o Zequinha, que me dava notícias sobre narrativas populares. O velho Ribas, seu Ribas, me contava coisas de antigamente, do fim do século passado ( século XIX), de crendices costumes que havia ainda, em Mogi das Cruzes. O Emílio Gredi, mateiro, me contava de plantas medicinais. Inácio Franco Pinto me acompanhava na pesquisa. Em Jacareí, já em 1949, Nena Pinheiro e Dadico me ajudaram muito, anotando narrativas, simpatias, quadrinhas. Em Suzano, Daniel Grijo, cantador, que, aliás, levei em 1968 para cantar na Faculdade de Filosofia de São Paulo para a turma do Antonio Candido, para a qual eu estava dando aula. Lazão que me ajudava a colher opiniões, relatos e fofocas em Suzano. Na Paraíba, já em 1969, Tita, o chofer da Faculdade de Filosofia, que, no caminho para o interior da Paraíba, me contou costumes dos muitos plantadores de abacaxi, das tradições em torno de certas capelas de João Pessoa, e também de feitiços.

No Ceará, no Crato, seu Pedro, um guarda da Faculdade de Filosofia, me deu tanta informação sobre Padre Cícero e abriu meus olhos para a verdadeira pesquisa que deveria ser feita: não apenas analisar os feitos de Padre Cícero, mas o que as pessoas acreditavam ser Padre Cícero, o que elas fizeram da figura de Padre Cícero.

PSO - Sei que, além dos caipiras, você também teve contatos com caiçaras. Seria interessante ouvir o que tem a dizer deles.

OEX - Em São Francisco, no litoral norte do Estado de São Paulo, pelos anos 50, lá estavam: Mané Boziano, Alexandre, Bidosa, Manango.

Manango, Mané Boziano e Alexandre eram pescadores, pescadores mesmo! Eles me ensinaram muita coisa sobre a pesca, sobre o mar, sobre a viração, sobre os dias próprios para pescar, os não próprios. Contaram da tragédia que era o vento da Bocaina, o vento que vem da montanha e arrasta tudo para o canal e para o mar aberto. E havia Bidosa - Bidosa, o cego. Esse era o mais importante porque até hoje é um mistério para mim. Bidosa era cego e era amparado pela comunidade. Bidosa tinha o trabalho diário de percorrer aquela rua única de São Francisco, aos brados, dizendo o que havia acontecido em São Paulo, o que o rádio deu. Eu me recordo de que, quando morreu Getúlio, ele passou dizendo: "Morreu Getúlio! Morreu Getúlio, minha gente! Morreu Getúlio!”. Assim foi, de ponta a ponta, até o convento, gritando. Mas a outra coisa importante, que é um mistério maior para mim: Bidosa servia de gávea. Isso é, ficava num lugar, para vigiar o mar - vigiar entre aspas, porque ele não enxergava o mar. Ele ficava numa posição, não sei como explicar, em que poderia avisar os caiçaras, os pescadores, da vinda do vento da Bocaina. Ele gritava, ele tocava uma espécie de corno e já avisava. Outro mistério!

PSO - O que este vento poderia causar para os pescadores? 
OEX - Arrastava todos os barcos, arrebentava tudo, até árvore ia junto. Arrancava tudo.

PSO - Ele avisava os pescadores porque sabia reconbecer a aproximação da mudança de vento, coisa que eles, os pescadores, não poderiam perceber?

OEX - Mas ele sabia reconhecer. Ele sentia, não sei se pela... não sei. É um mistério pra mim. Um outro mistério vou contar qual é. Esse Bidosa não só podia prever a vinda do vento da Bocaina, um vento muito perigoso, que vem da montanha e tudo arrasta para o mar aberto, mas também avisar, da vinda de cardumes. Como podia? Não sei. Ele avisava!

- Tem pescada! - gritava.

Além de gritar ele tocava três vezes, quatro vezes, avisando que havia peixe.

Agora, como a comunidade retribuía! Nos dias de pesca, todos os dias em que se pescava - duas, três vezes por semana - quando os barcos voltavam com o arrastão, acontecia a divisão do peixe: havia um tanto para as viúvas dos caiçaras; um tanto para os caiçaras doentes, que não podiam mais pescar; um tanto para o dono do barco e para sua família; um tanto para vender, se fosse possível, e um tanto para Bidosa. Está certo, certo, certo! Fazia parte do dia a dia, não se podia deixar de dar. Era religioso isso. Ele era mantido, compreende? Davam-lhe pilhas de radio, davam uma porção de coisa, sabe? Roupas, inclusive. Ele era cego de nascença, Bidosa.

Outro mistério, voltando a falar de Ururaí, era o Dito aleijado. Dito aleijado, preto, era um homem de uns quarenta anos, um homem forte, mas aleijado. ... Perdeu uma perna, usava muletas. Mas era Dito carreiro porque tinha carro de boi. Ele guiava o carro! Agora o mistério maior era o seguinte: como ele podia jogar futebol no gol? Ele jogava! Com a muleta, em cada braço. Ele fazia! Ele dava jeito, jogava futebol. Como?

Então, Bidosa e Dito Preto são das recordações mais lindas que eu já vi. Mas, agora há pouco eu estava falando de narrativas, e como poderiam ser aproveitadas, por gente que fosse escritor. Lá em Taiuva, em 1944, 1945, eu me recordo bem, numa véspera de São João, na fazenda do Seu Antenor Brandão, eu ouvi do Olavo - não me esqueço dele - um colono, a história da flor da samambaiaçu. Como ele contou, eu não sei repetir, foi uma coisa rica, muito bonita! Talvez eu pudesse reconstituir.

É assim: à meia-noite, na véspera de São João, samambaiaçu costuma dar uma flor, flor que rapidamente se transformava em fruto, e fruto que já cai e desaparece. Se alguém tiver disposição e coragem, fica ajoelhado perto da samambaiaçu e, se tiver chance de apanhar o fruto antes de ele cair, pega e já põe na boca. Então, se comer esse fruto, poderá pedir, das diversas coisas, o seguinte: ou ser um grande cantador, ou ser um grande domador de animais ou ser um grande conquistador. Mas acontece que ninguém até hoje conseguiu isso porque, quando já vai nascer e desabrochar a flor, começa um uivo muito forte, 
um barulho, um ronco muito feio. Aparece tudo quanto é espírito ruim, que não quer que a pessoa se aproveite. Geralmente a pessoa fica com medo e perde o fruto.

Esse senão, isso que pode acontecer para evitar que a pessoa atinja o objetivo, é muito comum em narrativa popular. Por exemplo: naquela fazenda das pedras, que antigamente era uma fazenda cheia de gado, gado miúdo, cheio de criação, de árvores, de plantas. Mas o dono era uma praga, um sujeito horroroso, tinha escravos. Se alguma rês se perdia, ele dava uma sova em todos os pretos; se alguma rês se matava, ele cortava o dedo de alguém, de um preto. Era uma maldade constante. Não dava nada para quem quer que fosse, nunca acolhia ninguém! Nada, nada, nada! Mas houve um dia, era véspera de Sábado de Aleluia, e vinha vindo um povo de retirantes na estrada. Na frente, vinha um beato e vinha atrás uma mulher com criança, mulher grávida, um homem doente, todos com fome, cansados. O beato avançou um pouco e disse para um preto:

- "Vê se arruma pra gente um pouco de leite, pra dar pras crianças."

- "E vocês estão querendo carnear, parece, porque amanhã é sábado, não é?"

- "Amanhã, quando der, dê um pouco de carne pra gente. Fale com o seu patrão pra dar."

O patrão veio correndo quando viu aquela gentarada:

- "O que é que essa gente quer?"

- "Eles querem leite pras crianças e um pouco de carne para amanhã."

- "Ah, não dou nada pra ninguém! Eles que vão embora. Prefiro ver a minha fazenda se transformar em pedra do que dar de comer pra vagabundo!"

- "Mas o pessoal tem fome, está doente...

- "Olhe, se você não for embora, eu já corto você."

- "Está bom, não precisa cortar..."

- "Eu corto você! Prefiro que minha fazenda vire uma coisa de pedra!"

Foi então que a fazenda do homem, na mesma hora, se transformou naquela andura. Só pedra, só cobra, só urtiga, só erva brava! Os pretos todos viraram pedra, toda gente, enfim, virou pedra também: pedra, pedregulho, pedrão, pedrinha. Galinha, tudo virou, tudo!

E assim vai ficar até o dia, em que, no sábado de Aleluia, o espírito deste homem ficar na beira da estrada, oferecendo coisa pra alguém: "Vem cá, vem comer, vem beber". Mas, acontece que quando vem alguém, os diabos vêm também e o pessoal vai embora. Então passa mais um ano, e a fazenda continua de pedra. A fazenda existe, viu?

É um processo em que, para se atingir uma coisa qualquer, passa-se pela intervenção de uma coisa negativa. Ninguém liberta aquela fazenda da maldição, da intervenção de coisas adversas. Isso é muito do povo, muito do povo. Toda hora o povo diz: "Não há bem que sempre dure nem mal que nunca se acabe". O povo diz isso. O povo sabe disso. 
Ah, outra coisa, na Ilha dos Búzios, em 1952, conheci seu Mateus, um patriarca. Foi a primeira vez que eu vi, de fato, um patriarca. Era muito popular e rezador, conselheiro, médico, ajudava a fazer parto, curava bicheira de vaca, curava doença de gente grande, dava conselhos e tudo o mais. Conheci a Nhá Bárbara, também. Era rezadora, fabricante de rabeca. Ela fabricava violino, rapaz! Nhec-nhec... que servia para as festas deles. Adorava ciranda, ou então, a dança do tamanco, não é? Fazia tudo isso.

Lá conheci João da Cruz, que era um capelão mesmo. Morava no Saco do Sombrio, em Ilhabela, mas foi rezar a novena de São Pedro na Ilha de Búzios. Ele me ensinou os lugares onde os piratas matavam gente, lá na costeira; era lá para o mar aberto e não para o canal. Ele me ensinou uma simpatia para se proteger das ossadas (ali enterradas). Era fazer um fogaréu no chão, depois esparramar a cinza em cruz e bater os dois pés três vezes para depois entrar lá naquela loca (pequena gruta), onde estavam os ossos.

PSO - E para sair de lá?

OEX - Para sair, rezava também. O pior era entrar. Para sair era só rezar um Pai-Nosso.

João da Cruz me falou também das lendas sobre os piratas e os tesouros enterrados:

- "Vem pra cá qualquer dia, professor. O senhor vai poder me ajudar. Eu sei aonde tem tesouro enterrado lá na Ilha de São Sebastião".

- "Qualquer dia a gente vem".

- "Mas venha logo porque aqui já tem gente com mapa e tudo!"

Quanto tesouro, quanta coisa enterrada! Mas, também, quantos espíritos ruins olhando tudo aquilo! Onde essa gente ruim enterrava tesouro, matava sempre duas ou três para ficar tomando conta. É outra forma de mostrar o senão, tão próprio destas narrativas populares, singelas e sábias, para quem as olha com atenção.

Panlo de Salles Oliveira é professor titular de Psicologia Social do Instituto de Psicologia da USP. @ - psalles@usp.br

Recebido em 15.9.2013 e aceito em 30.9.2013.

I Departamento de Psicologia Social e do Trabalho, Instituto de Psicologia. Universidade de São Paulo, São Paulo/SP, Brazil. 